\title{
ENGAGING BRAND COMMUNICATION IN FACEBOOK - A TYPOLOGY OF THE BRAND PAGE USERS
}

Yagodina Kartunova New Bulgarian University, Bulgaria yagodina4@gmail.com

\begin{abstract}
Facebook offers great opportunities for brands to connect with customers and build relationships with them in order to increase their loyalty and the company's sales. In regards to these goals, one of the most important key performance indicators is the customers' activity - liking, commenting, sharing, recommending, expressing love, etc. On one hand, there is a lot of research on customers' engagement, behavior and motivation. These studies provide valuable information for marketers to understand the way in which individuals use the social network and interact with others as well as the reasons behind their actions. Based on this knowledge they can develop their communication strategies and create content which has impact on the target audience. On the other, there are still some research gaps which can be further explored. One of them is related to the impact of one of the most important company assets - the brand culture, on the custom-
\end{abstract}

Digital Age in Semiotics \& Communication, Vol. I, No. 1, Spring 2018, Pp. 143-166 
er's behavior and willingness to become part of the digital brand story. This paper presents a Facebook brand page users typology, developed by using a semiotic approach, which is based on their brand culture adoption and brand narrative engagement.

Keywords: Facebook brand communication, brand culture, applied semiotics, digital communication

\section{Introduction}

The customers are the core of every marketing strategy - in digital media as well as in more traditional ones like television and radio. On the Internet, rich information is collected about every step of the user's online journey - websites visited, time spent on them, actions, interest, etc. Companies can buy or find every piece of the digital footprint of the target audience, and use it to craft their communication strategies and send highly targeted messages. But this is just one part of the knowledge they need to create iconic brands which build loyal relationships based on love with their customers. A quantitative survey of more than 10000 marketers from 92 countries, conducted by Harvard Business Review, reveals that brands are distinguished by their ability to integrate data on what consumers are doing with knowledge of why they are doing it, granting new insights about consumers' needs and how to best meet them (Arons, 2014). Facebook provides detailed statistics about their customers' characteristics and actions. These numbers are really valuable, but marketers need to combine them with deep understanding of customers' behavior, the way meaning is conveyed, the way customers interpret the brand messages, the motivation behind their actions, etc. This way companies can create value for the target audience and build relationships with the prospects.

By clicking on the Like button, Facebook users become fans of the brand, and if the algorithm of the social network decides that the content published by the company is relevant it appears on customers' newsfeeds. The trend over the last couple of years is that Facebook limits the brand content, or the so called organic reach. Experts believe that only $2 \%$ of brand fans see its posts if they are not sponsored. One of the main reasons is that the number of brands on the social network is increasing, and as Facebook wants to show relevant content which will engage the users, its algorithm focuses on the personal publications. That is why organic (nonpaid) visibility is becoming one of the main challenges for companies. One possible solution is to promote posts. The other is to create content which 
engages the customer and inspires interaction. The third one is to motivate the users to change their settings and choose to see every brand post - this is also related to building relationship with the target audience by creating meaningful content which leads to action.

The creation of engaging content, and building relationships with the target audience, are currently one of the main marketing challenges for companies. Although there is a lot of research related to this topic and their numbers is constantly increasing, there are still some gaps which are of importance for the development of successful corporate communication. One of them is the impact of a brand culture on the target audience's actions. This article aims to present a typology of the Facebook users of brand pages, based on their perception of the culture elements (values, rituals, hero, symbols) and their impact on customers' behavior. It will help marketers to segment the target audience, to create valuable and relevant content which drives customer behavior and which is valuable for the brand. Although it can be applied to other social media, our research focus is on Facebook since it is currently the most popular communication channel used by customers and companies. This study is related particularly to brand pages because that is the official place where a company can tell its mythological story, present its culture, and motivate users to become part of the brand story by developing it.

\section{Facebook and brand communication}

It has become a common truth that Facebook has changed the way individuals interact. The main goal of the social network is to connect people and give them a digital platform where they can communicate, exchange information, and most importantly develop their personal digital story and build their identities. The word "friend" has changed its meaning - on Facebook people connect not only with their strong ties (close friends and relatives) but also with their weak ties (acquaintances, even strangers with shared interests). This way they can create a large network of connections that can be extremely valuable for brands. Since 2009, posts from brands have begun to appear in the news feed. This way they become part of individuals' digital daily routine. By then the need to check the newsfeed on a daily basis had become a habit for individuals all over the world. Facebook states that people are interested in brands and use them to express themselves and build their identity. Mark Zuckerberg's team bases its decision on Marshall McLuhan's idea of a global villages connected with one universal communication platform (Kirkpatrick, 2011). In this way Facebook changes the relationship between a customer and a brand by offering on- 
going two-way communication in real time - something that is impossible in traditional media as well as in some new media formats.

With this new opportunity the brand experts face a new challenge how to create criteria for the success of the corporate communication on the social network. At the beginning marketers followed the same logic as in other new media channels - at that time advertisers payed for the number of impressions. According to this method, the number of fans becomes the main KPI (key performance indicator), as they are the potential receivers of brand messages. Marketing budgets are invested in increasing the number of brand page fans, and experts are trying to find a correlation between their number and the increase in sales. With time marketers came to understand that the quantitative factor cannot be the only indicator for success, and it is difficult to prove there is a direct link between an increase in fans and an increase in company sales. With time, communication experts changed their approach and started paying more attention to interactions with the fans and their feedback. They evaluate not only the immediate results such as the increase in sales but the long term benefits related to customers' behavior (building relationships, loyalty, etc.).

With the development of social media and improved tools for data analysis related to customers' behavior and pages' performance, communication is now focused on the engagement of the brand page's fans (Kleine-Kalmer 2016:12). More and more companies realize the opportunity to understand the customers' way of creating meaning and thus to build relationships with them, to exchange signs directly with the customers and thus influence their interpretation and brand perception which will lead to decision making. Currently fans' engagement rate and the number of people reached are the main KPIs for the success of brand pages on Facebook.

\section{Existing research}

\subsection{Customer engagement}

Customer engagement is defined as a contextual psychological state with cognitive, emotional, and behavioral dimensions that have different levels of intensity and play a major role in the relationship between the company and consumer (Brodie et al., 2011). This is related not only to purchase, but also to recommendation, active sharing of the positive experience with the brand (van Doorn et al., 2010), and repeat purchase and loyalty (Verhoef et al., 2010). Customers' engagement can have different value for the company depending on the following 4 components (Kumar et al., 2016):

- Brand purchase;

- Recommendation; 
- Influencing the opinion and behavior of other prospects;

- Feedback.

A study on customers' behavior (van Doorn et al., 2010) defines engagement as a "behavioral element which is not limited only to purchase", and is related to motivation (on a cognitive, behavioral and emotional level) to interact with the brand (ibid:253). The scientists based their survey on previous research on sales, word of mouth, recommendations, and publications, and take into account the preconditions and consequences of the audience's actions. As a result, they identify 5 aspects of consumer engagement (ibid: 255):

- Connotation: the way the customer sees the brand;

- Form or modality: the type of interaction the customer chooses to communicate with the brand;

- Reach: time (sporadic or long-term) and location (global or local) of the engagement;

- Impact: refers to the effect that the engagement has on the brand. It may be immediate or postponed in time, strong or weak, affecting many people or not, etc.;

- Consumer goals: if individual goals match and meet those of the brand, their engagement increases.

Based on Van Doorn's research, the marketing professor Gummerus (2012) analyses the customer engagement in the Facebook community. She believes that given the specifics of the social network, experts need to take into account the passive reading of posts which can also impact their behaviors. In her study Gummerus defines two types of customer engagement in a Facebook community (Kleine-Kalmer 2016:20):

- Related to the group: interactions with the other members and satisfying individual needs (likes, comments, etc.);

- Related to the brand: activity related to the brand.

The researchers discovered that most users are passive members of the group, but did not find the reasons behind this behavior. When building their corporate communication on the social network, the company must take into account both types of engagement-passive and active (Schau et al., 2009). The first is related to consuming and experiencing the brand's content by watching and reading. The second one inspires action in the form of liking or expressing other type of emotion, sharing the brand's content, generating one's own content related to the brand, etc. The main difference between the two is the user's decision to share her opinion with others or not. In regard to this, one of the biggest challenges for companies 
is to inspire active engagement, as it can have an impact on the opinion and behavior of the other prospects.

The most reputable research companies also conduct studies on customer engagement and share some important conclusions and definitions. Customer engagement is defined as the emotional bond between the company and its target audience, and has serious impact on the customer behavior (Gallup, 2014). According to the same study there are three types of customers - fully engaged, neutral, and actively not engaged; who are classified according to their answers to three main questions:

- The company always delivers what it promises;

- I am proud to be a customer of the brand;

- The brand is perfect for people like me.

In this regard, in order to motivate he customers to be actively engaged, companies need to focus on meeting the customer's expectations, on connecting with them on an emotional level, and on paying attention to the social factor and the user's need to belong to a group of people with shared interests. Companies need to inspire meaningful and relevant conversations and to match and even predict the dynamically developing needs of customers (SAP and Forbes, 2015). Customer engagement is the ongoing meaningful dialog between the brand and the individual, and is based on knowledge about the behavior and the needs of the target audience. The main challenges for companies is to effectively use social media and to meet customers' needs. Facebook is seen as the most effective social network which allows brands to connect with their customers, and therefore is one of the main important communication channels through which brands have the opportunity to communicate with the target audience and increase its engagement in order to build a strong brand community. This is accomplished through an ongoing process of delivering valuable and relevant content (Pulizzi, 2012).

\subsection{Brand communities}

Building a strong brand community is one of the most powerful marketing tools. Muniz and O'Guinn define the brand community as a specialized, non-geographically bound community based on a structured set of social relations among admirers of a brand (Muniz and O'Guinn, 2001:412). These are groups whose online interactions are based on shared enthusiasm for and knowledge about consumption practices (Kozinets, 1999). They are of different sizes and their members interact with each other in order to achieve shared as well as personal goals (Dholakia et al., 2004). One of its 
most important aspects is that the brand community creates subcultures with its own myths, values, rituals, hierarchy, and tone of voice (Cova and Pace, 2006). In modern society, different forms of subculture unite individuals through shared experiences based on common beliefs, lifestyles and consumer behaviors (Cova et al., 2012). Despite the possibility of different motivations for participation, members of the group certainly share one thing-the creation and negotiation of meaning (McAlexander et al., 2002). Brands evolve in the digital space and increase their value in the ongoing process of sharing meaning among individuals (Patterson and O'Malley, 2006). Customers who are members of the brand community feel more connected with the brand compared to the others (Kim et al., 2008). Building a brand community in social media could have a positive impact on the relationship between the brand and the target audience, as well as increase the company's sales (Kumar et al., 2016). In summary, users can create value for the brand by participating in the brand community as they:

- Contribute to the interaction between members and increase their engagement;

- Create positive brand content;

- Improve the brand usage (Schau et al., 2009).

Some researchers consider brand communities and brand pages to be similar things as they are both related to positive customers' attitude (Dessart et al., 2015). "Since brand fan pages are organized around a single brand, product, or company, they can be seen as a special kind of brand community" (Kunz and Benedikt, 2012:347), though there is no scientific proof that brand pages are equal to a brand community. The expert Melanie Zaglia (2013) conducts a netnography research on the two ways to create a brand community on Facebook - brand pages, and groups. She concludes that the page is the weaker form of community, and differs significantly from the group. Other research proves that a very small percentage of a brand page's fans are active on it (Kleine-Kalmer, 2016:53-54), which is opposed to the idea of shared rituals and behavioral practices intrinsic to community. Creating a Facebook brand page does not necessarily lead to building a brand community, and the two concepts need to be distinguished. Companies need to create and develop a successful communication strategy in order to transform the group into a community. This success is based on shared values and the brand culture, represented by the brand story. In order to convey meaning in a comprehensible and effective way, the company must explore and understand their behavior, which is related to their moti- 
vation and emotions, which are both in turn affected by culture (de Mooij and Hofstede, 2011:186).

\subsection{Customers' motivation}

The relation between brand content and customers' motivation leads to engagement and positive attitude towards the brand (Van Doorn et al., 2010). A great part of the research on brand communities aims at identifying the customers' motivation to participate in them. Motivation is an intrinsic desire to satisfy a need or a desire (Deci and Ryan, 1985). From the definition becomes clear that motivation is related to action. In brief, there are several motivations for liking a Facebook brand page:

- Connecting with others, satisfying the need of belonging to a group of like-minded people (Bosch, 2009; Sheldon, 2008);

- Building identity, self-realization (Joinson, 2008);

- Sharing and searching for information, learning new things (Raacke and Bonds-Raacke, 2008; Bosch, 2009; Pempek et al., 2009);

- Entertainment, hedonistic motivation (Lewis and West, 2009; Joinson, 2008; Sheldon, 2008).

In order to build a successful corporate communication strategy on Facebook, companies need to understand not only users' motivation for liking the brand page but also the factors which influence their activity and engagement. Although most studies focus on the reasons for joining the brand group, some researchers study the motivations for interacting with brand content. Kunz and Benedikt (2012), for example, study the impact of brand pages on the relationship between users and the brand, and outline some important conclusions (Kunz and Benedikt, 2012:354):

- The activity of the others motivates users in the group to be active too;

- Shared values are one of the most important factors for building a relationship and increasing customer engagement;

- Interaction between the members of the page increases their engagement;

- Companies must deliver value to their fans, or they will be passive and may even unlike the page-the more the brand page satisfies the consumers' needs and delivers value, the greater the opportunity for its fans to be active.

Another study on the customers activity provides interesting findings (Wirtz et al., 2013): 
- Relationship with the brand: the more the individual recognizes the values and identity of the brand, the more he feels connected to its members.

- The value of participating in the brand community: it is related to the relevance of the information and the special incentives the company offers;

- The structure of the community: the size and the development of the page affects the engagement of its fans.

In brief, researchers outline several reasons for users' activity: liking the brand, interaction, obtaining practical incentives, entertainment, and image building.

On Facebook, customers use brands as symbols for certain meanings, social status, interests, etc. On one hand they use Facebook as a tool to build their desired image, and on the other they indicate whether other users have similar values and beliefs. The desire to connect and build an image are the main reasons for active engagement (Dholakia et al., 2004:259). Trust is another important factor which influences a user's activity level. That is why if the company publishes content which shows the individual that it shares her values and corresponds to her lifestyle, it can decrease feelings of insecurity and increase the feeling of community. If the company helps the user to express herself, it increases her love and her willingness to share it (Wallace et al., 2014). From a cognitive point of view, social identity is related to the awareness of similarities between group members and differentiation from others (Dholakia et al., 2004: 245). This is why companies need to align every post with their brand culture and focus on the shared values of customers in order to increase their activity and engagement.

\subsection{Limitations and opportunities}

Although there is a growing body of research on brand communication and its impact on customers' engagement, there is still an opportunity to gain more knowledge on customers' behavior. The main gap is a study which shows how brand elements affect engagement. Most studies aim at clarifying the motivation of users, as it impacts their decision to be active or passive and is an important factor for building a brand community. However, there is no research which studies how the brand culture affects this motivation. "Motivation is an assumed force operating inside an individual, inducing him or her to choose one action over another. Culture as collective programming of the mind thus plays an obvious role in motivation. Culture influences not only our behaviors but also the explanations 
we give for our behaviors" (Hofstede et al., 2010: 327). In regard to this, a typology which takes into account the willingness of different types of fans to connect with the brand story and the impact of the values, rituals, brand heroes and symbols on it, will deepen the knowledge about the customers' behavior in Facebook. It answers important questions related to the motivations of different users to engage with the brand mythology and the role of the shared rituals, connecting the brand and the role of brand culture with the purchase intent. The answers will help experts build corporate communication which builds brand communities and actively engage their fans.

\section{Facebook brand page users' typology}

Individuals intuitively classify other people as "we" (part of their community) or "they" (not part of their community) (Hofstede et al., 2010:16). They make this judgment based on their culture (values, beliefs) which impact the way they create and interpret meaning. "Most people most of the time are busy being good members of the groups to which they belong" (ibid:17). This logically determines their behavior. Hofstede believes that technological developments and digital media are a mirror to the customer's behavior, but while they affect the outer cultural layers (symbols, heroes, consumption practices) they do not have an influence upon the values which remain more or less the same (ibid:19). Values are implicit, which is why they are not affected by fashionable trends or by the dynamic development of new media. This is the main reason they could be the core of a successful communication strategy which brings value and powerful meanings to customers. Nevertheless, cultural elements have a different impact on the various types of users of brand pages in Facebook. That is why marketers need to study their specific influence in order to create targeted brand messages.

The typology of Facebook band page users proposed in this paper is created after conducting various kinds of research - a brand page semiotic analysis, a netnographic research, a qualitative study, and a quantitative study.

The purpose of the typology is to classify Facebook fan page users into categories which are valid for all brand pages; but in order to collect the necessary primary data for the analysis, the study began with a specific study - the brand page of Johnnie Walker www.facebook.com/ JohnnieWalkerBulgaria/). This page was chosen because the brand has a powerful mythological story and a well-recognized hero, and the company states that the culture of the brand and its customers is at the core of its 
communication and success (Epstein, 2014). The Facebook page of Johnnie Walker is aligned with this marketing strategy and develops the brand story. Every post is part of the coherent brand text and conveys the brand meanings, thus creating the brand myth. The great myths are based on the empathic understanding of the greatest human desires and fears because they have an impact on the whole society (Holt, 2004:212). As a result, companies can create cultural texts which reflect the existential concerns of the society. The posts of Johnnie Walker can be classified into 5 main types:

- Company values: the brand posts motivational quotes on a weekly basis related to the customers' and brand's values. They reflect the personal desire to develop and self-realize. The brand becomes a signifier of personal growth and inner strength. These posts are the most engaging as they motivate users to be active - to like, share, comment and express love with emoticons, etc.

- Lifestyle symbols: the second level of meaning of some posts creates the ideal lifestyle for the target audience by using symbols such as an expensive watch (professional success), camera (travel), skyscraper (high achievement), etc.

- Ritual of exchange: some of the brand posts initiate meaning transfer and present the product as the perfect gift.

- Symbols of consumption: the most recognizable communication codes related to the whiskey category are ice and the specific glasses, which are aimed at increasing the desire to consume the product.

- Symbols of heritage: other strong symbols used by the brand are related to its historical heritage because consumers associated it with quality (for example the barrel).

After identifying the different brand posts based on its culture, a netnographic study was conducted in order to identify the behavior, motivations, culture, values and norms of the Johnnie Walker Facebook page fans. Netnography is the use of ethnographic approach to study online culture and societies (Kozinets 2010:6). It studies ideas, social practices, relations, languages and symbol systems. In order to identify different types of fans based on their reactions and attitudes towards the brand culture, all the posts and actions on the Johnnie Walker Facebook page from the brand and its users were studied. This analysis was followed by a qualitative study. 8 fans participated in semi-structured in-depth interviews conducted to find out more about their perceptions of the brand culture and its impact on their passive or active behavior. The research questions were: 
- What is the motivation of the users to like a Facebook brand page?

- Is this motivation linked to the user's expectations for the brand content?

- Is this motivation linked to the user's activity on the page afterwards?

- How the brand culture elements impact the user's activity?

- Does the image on Facebook, built by the user, affect her activ ity on the brand page?

- To what extent the motivation for active behavior is influenced by the other brand page fans?

- Is there a correlation between the user's activity on the brand page and the intention to use the product/service?

Besides the questions, the respondents were shown different types of brand posts in order to collect data about their reactions and perceptions.

Then a quantitative study with 100 respondents was conducted in order to verify the primary data and the research hypothesis formulated during the previous stages (see Appendix 1). The research questions were:

- To what extent the different types of users are willing to link their personal story on Facebook to the brand story?

- To what extent are the users willing to participate in brand rituals?

- To what extent do the users tend to learn the whole story of the brand narrated in the various new media channels?

- Do the users identify with the brand and its values?

- Which elements of the brand culture (values, hero, symbols) impact the user's activity?

- What are the reasons for their active and passive behavior?

- What would motivate the different types of users to interact with the other page fans and create brand community?

As a result, 4 types of Facebook brand page users were identified based on their willingness to share the brand story and their attitude towards the brand:




Based on the impact that brand culture elements have on users' willingness to share and develop the brand story, 4 main types of users were identified: seekers, influencers, supporters and detached storytellers.

- Seekers: their motivation to like the page is functional and related to the individual desire to win/to get an incentive: "If the prize is attractive enough for me, I would like any kind of brand page". At the beginning they are active only if they see the opportunity to receive an incentive. However, if the brand values appeal to their personal values, they are willing to follow the brand story on other digital channels and even to share it.

- Influencers: they love the brand and want to be part of its digital life and story. They appreciate not only the functional benefits of the brand but focus on the emotional connection: "I just feel like receiving updates from a dear friend and I do not want to miss anything". They want to join and share not only the digital brand story but want to participate in offline events. The influencers identify with the brand values and build their image based on them.

- Supporters: the largest group of the brand page users. The brand expresses their lifestyle, they like it and they use it to build their online image: "I want the others to see that I have unique personality". If the brand gives them value, they feel engaged and they share and develop the brand story.

- Detached: they like the page because somebody has asked them to, or Facebook has suggested a page for them. At the beginning they are passive, they do not recognize the brand values and culture: "I noticed that a lot of my friends with similar interests have liked the page and I decided to give it a chance". If the brand succeeds in delivering value to this type of customer and, most importantly, they identify with the brand values, they could become supporters. Otherwise they are likely to unlike the page or remain passive.

Below is a table with a brief summary of their profiles:

\begin{tabular}{|c|l|l|l|l|}
\hline & \multicolumn{1}{|c|}{ Seekers } & \multicolumn{1}{c|}{ Influencers } & \multicolumn{1}{c|}{ Supporters } & \multicolumn{1}{c|}{ Detached } \\
\hline $\begin{array}{c}\text { Main reason } \\
\text { for liking the } \\
\text { FB brand page }\end{array}$ & $\begin{array}{l}\text { The incen- } \\
\text { tives, of- } \\
\text { fered by the } \\
\text { company }\end{array}$ & $\begin{array}{l}\text { Love the brand } \\
\text { and want to be } \\
\text { part of its digital } \\
\text { story }\end{array}$ & $\begin{array}{l}\text { Feel positive } \\
\text { about the brand } \\
\text { tions - because a } \\
\text { friend has asked } \\
\text { them or many } \\
\text { other friends } \\
\text { have liked it, etc. }\end{array}$ \\
\hline
\end{tabular}




\begin{tabular}{|c|c|c|c|c|}
\hline $\begin{array}{l}\text { Main motiva- } \\
\text { tion }\end{array}$ & Pragmatic & Emotional & $\begin{array}{l}\text { Emotional and } \\
\text { pragmatic }\end{array}$ & $\begin{array}{l}\text { Emotional and } \\
\text { pragmatic }\end{array}$ \\
\hline $\begin{array}{l}\text { Reasons for } \\
\text { active behav- } \\
\text { ior }\end{array}$ & $\begin{array}{l}\text { Posts which } \\
\text { appeal to } \\
\text { the users' } \\
\text { identity. } \\
\text { Posts with } \\
\text { brand am- } \\
\text { bassadors. }\end{array}$ & $\begin{array}{l}\text { Want to share } \\
\text { their love. } \\
\text { Want to build } \\
\text { and image of a } \\
\text { brand expert. } \\
\text { Use the brand } \\
\text { as a symbol of } \\
\text { their identity. } \\
\text { Seek appreci- } \\
\text { ation from the } \\
\text { brand. }\end{array}$ & $\begin{array}{l}\text { Relevant brand } \\
\text { information } \\
\text { (new products, } \\
\text { interesting in- } \\
\text { formation, tips } \\
\text { on product us- } \\
\text { age, etc.) } \\
\text { Posts which } \\
\text { appeal to their } \\
\text { identity and } \\
\text { values }\end{array}$ & $\begin{array}{l}\text { Relevant and use- } \\
\text { ful information } \\
\text { for the brand's } \\
\text { category. } \\
\text { Posts which ap- } \\
\text { peal to the users' } \\
\text { identity. } \\
\text { Posts with brand } \\
\text { ambassadors. }\end{array}$ \\
\hline $\begin{array}{l}\text { Reasons for } \\
\text { passive behav- } \\
\text { ior }\end{array}$ & $\begin{array}{l}\text { Content } \\
\text { which is } \\
\text { not inter- } \\
\text { esting and } \\
\text { does not } \\
\text { bring ex- } \\
\text { citement. } \\
\text { Advertise- } \\
\text { ments. }\end{array}$ & Advertisements. & $\begin{array}{l}\text { Content which } \\
\text { does not appeal } \\
\text { to their identity. } \\
\text { Advertisements. }\end{array}$ & $\begin{array}{l}\text { At first they are } \\
\text { not active be- } \\
\text { cause they do } \\
\text { not know what } \\
\text { to expect from } \\
\text { the brand, they } \\
\text { do not connect } \\
\text { with the brand } \\
\text { story before they } \\
\text { get enough in- } \\
\text { formation about } \\
\text { its identity and } \\
\text { image. } \\
\text { Advertisements. }\end{array}$ \\
\hline $\begin{array}{l}\text { Main mo- } \\
\text { tivation for } \\
\text { interactions } \\
\text { with the other } \\
\text { brand page } \\
\text { fans }\end{array}$ & $\begin{array}{l}\text { The de- } \\
\text { sire to } \\
\text { share their } \\
\text { knowledge }\end{array}$ & $\begin{array}{l}\text { If they have met } \\
\text { them in per- } \\
\text { son on a brand } \\
\text { event. } \\
\text { To support } \\
\text { them. } \\
\text { To connect with } \\
\text { like-minded } \\
\text { people. } \\
\text { To share the } \\
\text { same values. } \\
\text { To feel part of a } \\
\text { group. }\end{array}$ & $\begin{array}{l}\text { Share their } \\
\text { knowledge. } \\
\text { If they have met } \\
\text { them personally } \\
\text { on an event. }\end{array}$ & No motivation. \\
\hline $\begin{array}{l}\text { Impact of } \\
\text { their activity } \\
\text { on the willing- } \\
\text { ness to use the } \\
\text { product }\end{array}$ & Medium & High & High & Medium \\
\hline
\end{tabular}




\begin{tabular}{|c|c|c|c|c|}
\hline $\begin{array}{l}\text { Main actions } \\
\text { on the page }\end{array}$ & $\begin{array}{l}\text { Like. } \\
\text { Share. } \\
\text { Rate the } \\
\text { product. } \\
\text { Invite } \\
\text { friends to a } \\
\text { brand event } \\
\text { or game. } \\
\text { Join a } \\
\text { cause, sup- } \\
\text { ported by } \\
\text { the brand. }\end{array}$ & $\begin{array}{l}\text { Like almost ev- } \\
\text { ery brand post. } \\
\text { Share and com- } \\
\text { ment. } \\
\text { Express love } \\
\text { with emoticons. } \\
\text { Invite friends to } \\
\text { a brand event or } \\
\text { game. } \\
\text { Rate and recom- } \\
\text { mend. } \\
\text { Post on the wall. } \\
\text { Join a brand } \\
\text { cause. }\end{array}$ & $\begin{array}{l}\text { Like } \\
\text { Share and com- } \\
\text { ment. } \\
\text { Invite friends to } \\
\text { a brand event or } \\
\text { game. } \\
\text { Rate and rec- } \\
\text { ommend. } \\
\text { Write a personal } \\
\text { message to the } \\
\text { brand. } \\
\text { Join a brand } \\
\text { cause. }\end{array}$ & $\begin{array}{l}\text { Like. } \\
\text { Share relevant } \\
\text { information with } \\
\text { a friend. } \\
\text { Join a brand } \\
\text { cause. }\end{array}$ \\
\hline $\begin{array}{l}\text { Interest in } \\
\text { following the } \\
\text { brand story on } \\
\text { other digital } \\
\text { channels }\end{array}$ & $\begin{array}{l}\text { Follow a } \\
\text { link to the } \\
\text { brand web- } \\
\text { site, down- } \\
\text { load free } \\
\text { content }\end{array}$ & $\begin{array}{l}\text { Highly likely } \\
\text { to follow the } \\
\text { brand story on } \\
\text { the other dig- } \\
\text { ital channels: } \\
\text { the company's } \\
\text { website, news } \\
\text { related to the } \\
\text { brand, other } \\
\text { brand social } \\
\text { media pages, } \\
\text { download free } \\
\text { content, down- } \\
\text { load brand ap- } \\
\text { plication, click } \\
\text { on a banner, etc. } \\
\text { Want to be part } \\
\text { of the offline life } \\
\text { of the brand. }\end{array}$ & $\begin{array}{l}\text { Highly likely } \\
\text { to follow the } \\
\text { brand story on } \\
\text { the other dig- } \\
\text { ital channels: } \\
\text { the company's } \\
\text { website, news } \\
\text { related to the } \\
\text { brand, other } \\
\text { brand social } \\
\text { media pages, } \\
\text { download free } \\
\text { content, down- } \\
\text { load brand ap- } \\
\text { plication, click } \\
\text { on a banner, etc }\end{array}$ & $\begin{array}{l}\text { Follow a link to } \\
\text { the brand web- } \\
\text { site. } \\
\text { Read brand news. } \\
\text { Download free } \\
\text { content. }\end{array}$ \\
\hline $\begin{array}{l}\text { Impact of the } \\
\text { brand rituals }\end{array}$ & No & $\begin{array}{l}\text { React posi- } \\
\text { tively to posts } \\
\text { which show the } \\
\text { product as part } \\
\text { of the rituals } \\
\text { of exchange, } \\
\text { possession and } \\
\text { even grooming }\end{array}$ & $\begin{array}{l}\text { Willing to par- } \\
\text { ticipate in the } \\
\text { ritual of ex- } \\
\text { change }\end{array}$ & No \\
\hline $\begin{array}{l}\text { Impact of the } \\
\text { brand hero }\end{array}$ & $\begin{array}{l}\text { No, they } \\
\text { prefer fa- } \\
\text { mous peo- } \\
\text { ple to be } \\
\text { brand am- } \\
\text { bassadors }\end{array}$ & $\begin{array}{l}\text { Build their im- } \\
\text { age using the } \\
\text { brand and want } \\
\text { to be associated } \\
\text { with the brand } \\
\text { hero }\end{array}$ & $\begin{array}{l}\text { React very pos- } \\
\text { itively to brand } \\
\text { ambassadors } \\
\text { and the brand } \\
\text { hero if they } \\
\text { identify with } \\
\text { them }\end{array}$ & $\begin{array}{l}\text { React very } \\
\text { positively } \\
\text { to brand } \\
\text { ambassadors and } \\
\text { brand hero if } \\
\text { they identify with } \\
\text { them }\end{array}$ \\
\hline
\end{tabular}




\begin{tabular}{|c|l|l|l|l|}
\hline $\begin{array}{c}\text { Impact of the } \\
\text { brand symbols }\end{array}$ & No & $\begin{array}{l}\text { Recognize the } \\
\text { brand symbols } \\
\text { and they in- } \\
\text { crease their will- } \\
\text { ingness to use } \\
\text { the product }\end{array}$ & $\begin{array}{l}\text { Recognize the } \\
\text { brand sym- } \\
\text { bols and they } \\
\text { increase their } \\
\text { desire to share } \\
\text { value-creating } \\
\text { practices }\end{array}$ & No \\
\hline $\begin{array}{c}\text { Impact of the } \\
\text { brand values }\end{array}$ & $\begin{array}{l}\text { with the } \\
\text { brand } \\
\text { values, no } \\
\text { emotional } \\
\text { connection } \\
\text { with the } \\
\text { brand }\end{array}$ & $\begin{array}{l}\text { Sartially } \\
\text { tify with the } \\
\text { and they react } \\
\text { mostly to posts } \\
\text { related to the } \\
\text { brand identity }\end{array}$ & $\begin{array}{l}\text { The brand val- } \\
\text { important ele- } \\
\text { ment }\end{array}$ & $\begin{array}{l}\text { If they identify } \\
\text { with the brand } \\
\text { values, they are } \\
\text { likely to become } \\
\text { supporters. }\end{array}$ \\
\hline $\begin{array}{c}\text { Consumption } \\
\text { practices }\end{array}$ & No & $\begin{array}{l}\text { Willing to } \\
\text { participate in } \\
\text { almost every } \\
\text { consumption } \\
\text { practice related } \\
\text { to the brand }\end{array}$ & Yes & No \\
\hline $\begin{array}{c}\text { Willingness } \\
\text { to share and } \\
\text { develop the } \\
\text { brand story }\end{array}$ & Yes & Yes & Yes \\
\hline
\end{tabular}

\section{Conclusion}

The cultural perspective offers great opportunities to the communication experts to understand individuals' meaning creation, which drives their motivation to feel engaged and to be active. Some of the main insights from the study of the different types of Facebook brand page users are:

- Brands can motivate every type of user to develop and share the brand myth if it helps them to build their own digital story;

- Values are the most important element which motivates action;

- People feel more engaged and as part of a brand community if they experience the brand story offline, not just online;

- People want brands which help them to build their ideal identity;

- People want to follow the brand story on other digital channels, etc. 


\section{Appendix 1}

Questions for the quantitative study:

1. Which statement is the most relevant for you? I like a brand page on Facebook if:

- the brand can offer me something useful: promotions/tips on product use/interesting events/rewards, etc.

- I love the brand. I want to receive information about it and be part of its Facebook community.

- I like the brand. I expect it to publish information that can be useful/ fun/interesting/valuable.

- my friend suggested it for me/ I saw that my friends have liked it/Facebook offered me to like it.

2. How likely would you do the following things? Please give an answer on each line on a scale of 1 (unlikely), 3 (neutral) to 5 (highly probable):

- join a group with other brand fans;

- publish results from a brand mobile app in your profile;

- write a personal message to the brand;

- like a brand post;

- comment on a brand post;

- mention your friend in a brand post;

- share a brand post;

- write on the brand wall;

- recommend or rate the brand;

- ask your friend to like the page;

- invite your friend to a brand event;

- invite your friend to participate in a brand game;

- mention the brand in a personal post;

- share a photo with/of the brand in your profile;

- use a photo with/of the brand for a cover photo;

- link your family status to the brand;

- use the brand name for your own;

- use a brand picture for your profile picture.

3. How likely would you do the following things? Please give an answer on each line on a scale of 1 (unlikely), 3 (neutral) to 5 (highly probable):

- send a post to your friend;

- send a greeting/photo with the brand logo to a friend; 
- send a virtual product to a friend;

- participate in a game, regularly organized by the brand;

- participate in an event, regularly organized by the brand;

- use an emoticon created by the brand for personal communication.

4. How likely would you do the following things? Please give an answer on each line on a scale of 1 (unlikely), 3 (neutral) to 5 (highly probable):

- follow a link to the brand website;

- like/follow the brand on other social networks (eg. Instagram);

- subscribe to the YouTube channel of the brand;

- go directly to the brand website;

- subscribe to a brand newsletter;

- click on a brand banner;

- read a brand news;

- download free content created by the brand (e-book, white paper, etc.);

- use an app created by the brand.

5. How would you describe the brand with one word? Please choose one answer:

- creator: crafts something new;

- caregiver: cares for others;

- ruler: exerts control;

- jester: has a good time;

- regular guy: ok just as they are;

- lover: finds and gives love;

- hero: acts courageously;

- outlaw: breaks the rules;

- magician: affects transformation;

- innocent: retains or renews faith;

- explorer: maintains independence;

- sage: understands the world.

6. How would you describe yourself with one word? Please choose one answer:

- creator: crafts something new;

- caregiver: cares for others;

- ruler: exerts control;

- jester: has a good time; 
- regular guy: ok just as they are;

- lover: finds and gives love;

- hero: acts courageously;

- outlaw: breaks the rules;

- magician: affects transformation;

- innocent: retains or renews faith;

- explorer: maintains independence;

- sage: understands the world.

7. What could motivate you to be active. Please choose all the relevant answers:

- the brand is like me (my identity);

- the hero (if any) is like me (eg. Johnnie Walker's striding man, Captain Morgain's pirate, etc.);

- a post with a famous person using the brand;

- the people used for the brand visuals/video are like me and do things which I like to do myself;

- the brand's symbols give me positive feelings (Apple's bite apple, Johnnie Walker's bottle cut, Coca-Cola red color, etc.);

- something else.

8. What makes you passive? Please choose all the relevant answers:

- the post is not interesting;

- the post is not exciting;

- the post does not appeal to my identity;

- I do not want the others to see what I am doing on Facebook;

- something else.

9. What can motivate you to interact with the other brand page fans? Please choose all the relevant answers:

- the desire to share my knowledge about the topic of the post/ question/comment;

- nothing can motivate me to interact with them;

- something else.

10. Does you activity on the brand page increase your willingness to use the brand? Please choose all the relevant answers:

- yes, definitely;

- rather yes;

- rather not;

- no, definitely;

- I can not decide. 
11. Your gender:

- female;

- male.

12. Your age:

- 18 or under;

- 18-24;

$-25-34$

- 35-44;

- 45-54;

$-55+$

13. Your residence

14. Your educational level 


\section{References}

Algesheimer, René. Dholakia, Utpal M. Herrmann, Andreas. 2005. The social influence of brand community: evidence from European car clubs. Journal of Marketing 69 (3) 19-34

Arnone, Laurent. Colot, Olivier. Croquet, Mélanie. Pozniak, Laetitia. 2010. Company Managed Virtual Communities in Global Brand Strategy. Global Journal of Business Research 4 (2), 97-111

Arons, Marc de Swaan. 2014. The Ultimate Marketing Machine. Available on: https://hbr.org/2014/07/the-ultimate-marketing-machine [last accessed: 1 May 2017]

Bosch, T. E. 2009. Using online social networking for teaching and learning: Facebook use at the university of cape town. Communication: South African Journal for Communication Theory and Research 35 (2), 185-200

Brodie, Roderick. Hollebeek, Linda. Jurić, Biljana. Ilić, Ana. 2011. Customer Engagement, Journal of Service Research 14 (3), 252-271

Cova, Bernard. Kozinets, Robert. Shankar, Avi. 2012. Consumer Tribes, Oxford: Elsevier

Cova, Bernard. Pace, Stefano. 2006. Brand community of convenience products: new forms of customer empowerment - the case 'my Nutella The Community'. European Journal of Marketing 40 (9/10), 1087-1105

Deci, Edward. Ryan, Richard M. 1985. Intrinsic motivation and selfdetermination in human behavior. New York: Plenum.

De Mooij, Marieke. Hofstede, Geert. 2011. Cross-Cultural Consumer Behavior: A Review of Research Findings, Journal of International Consumer Marketing 23 (3-4), 181-192

Dessart, Laurence. Veloutsou, Cleopatra. Morgan-Thomas, Anna. 2015. Consumer engagement in online brand communities: a social media perspective, Journal of Product \& Brand Management 24 (1), 28-42

Epstein, Eli. (2014). The Johnnie Walker Brand: A Rich Blend of Design and Progress. Available on: http://mashable.com/2014/05/02/johnnie-walker-marketing-strategy/\#U3TuY5Kudsqu [last accessed on: 3 Oct 2017] 
Gallup. 2017. Customer engagement. Available on: http://www.gallup. com/services/169331/customer-engagement.aspx [last accessed: 1 Sept 2017]

Gummerus, Johanna. Liljander, Veronica. Weman, Emil. Pihlström, Minna. 2012. Customer engagement in a Facebook brand community. Management Research Review, 35 (9), 857 - 877

Hofstede, Geert. Hofstede, Gert Jan. Minkov, Michael. 2010. Cultures and Organizations: Software of the Mind, New York: McGraw-Hill

Holt, Douglas B. 2004. How Brands Become Icons: The Principles of Cultural Branding, Boston: Harvard Business Press

Joinson, Adam N. 2008. 'Looking at', 'Looking up' or 'Keeping up with' people? Motives and uses of Facebook. In Proceedings of the 26th annual SIGCHI conference on human factors in computing systems. 1027-1036. New York: ACM

Kim, Jae Wook. Choi, Jiho. Qualls, William. Kyesook, Han. 2008. It takes a marketplace community to raise brand commitment: the role of online communities, Journal of Marketing Management 24 (3-4), 409-431

Kirkpatrick, David. 2011. The Facebook Effect: The Inside Story of the Company That Is Connecting the World. New York: Simon and Schuster

Kleine-Kalmer, Barbara. 2016. Brand Page Attachment: An Empirical Study on Facebook Users' Attachment to Brand Pages. Bremen: Springer

Kozinets, Robert. 1999. E-Tribalized Marketing? The Strategic Implications of Virtual Communities of Consumption, European Management Journal 17 (3), 252-264

Kozinets, Robert V. 2010. Netnography, London: SAGE Publications Inc

Kumar, Ashish. Bezawada, Ram. Rishika, Rishika, Janakiraman, R Ramkumar. 2016. From Social to Sale: The Effects of Firm Generated Content in Social Media on Customer Behavior. Journal of Marketing 80 (1), 7-25

Kunz, Werner. Benedikt, Jan. 2012. How to transform consumers into fans of your brand, Journal of Service Management 23 (3), 344-361

Lewis, Jane. West, Anne. 2009. 'Friending': London-based undergraduates' experience of Facebook. New Media \& Society, 11 (7), 1209-1229 
McAlexander, James H. Schouten, John W. Koenig, Harold F. 2002. Building Brand Community, Journal of Marketing 66 (1), 38-54

McCracken, Grand David. 1986. Culture and Consumption: A Theoretical Account of the Structure and Movement of the Cultural Meaning of Consumer Goods, Journal of Consumer Research 13 (1), 71-84

McCracken, Grand David. 1990. Culture and Consumption: New Approaches to the Symbolic Character of Consumer Goods and Activities, Bloomington: Indiana University Press

Muniz, Albert. O'Guinn, Thomas. 2001. Brand Community, Journal of Consumer Research 27 (4), 412-432

Patterson, Maurice. O’Malley, Lisa. 2006. Brands, consumers and relationships: A review, Irish Marketing Review 18 (1/2), 10-20

Pempek, Tiffany A. Yermolayeva, Yevdokiya. Calvert, Sandra. 2009. College students' social networking experiences on Facebook. Journal of Applied Developmental Psychology 30 (3), 227-238

Pulizzi, Jonathan. 2012. The Rise of Storytelling as the New Marketing. Available on: https://odonnetc.files.wordpress.com/2014/09/the-rise-ofstorytelling-as-the-new-marketing.pdf [last accessed: 30 Sept 2017]

Raacke, John. Bonds-Raacke, Jennifer. 2008. MySpace and Facebook: Applying the Uses and Gratifications Theory to Exploring Friend-Networking Sites, Cyber Psychology \& Behavior 11 (2), 169-174

SAP. 2013. Social Media Analysis and Audience Engagement. Available on: https://www.sapvirtualagency.com/FileExplorer/Partners/SAP\%20 Business\%20Analytics\%20Solutions/Web\%20Feed/Cloud\%20for\%20Social/MED_SID_ID0280_V01_Social_Media_Analysis.pdf [last accessed: 30 Sept 2017]

Schau, Hope Jensen. Muñiz, Albert M. 2009. How Brand Community Practices Create Value. Journal of Marketing 73 (5), 30-51

Sheldon, Peter. 2008. Student favourite: Facebook and motives for its use. Southwestern Mass Communication Journal 23 (2), 39-53

van Doorn, Jenny. Lemon, Katherine N. Mittal, Vikas. Nass, Stephan. Pick, Doreén. Pirner, Peter. Verhoef, Peter C. 2010. Customer Engagement 
Behavior: Theoretical Foundations and Research Directions. Journal of Service Research 13 (3), 253-266

Verhoef, Peter. Reinartz, James. Krafft, Michael. (2010). Customer engagement as a new perspective in customer management. Journal of Service Research, 13 (3), 247-252

Zaglia, Melanie. 2013. Brand communities embedded in social networks, Journal of Business Research 66 (2), 216-223 